\title{
Modeling Survival and Destruction of Teak Plantations in Java, Indonesia
}

\author{
Tatang Tiryana ${ }^{* 1,2}$, Satoshi Tatsuhara ${ }^{* 1}$ and Norihiko Shiraishi ${ }^{* 1}$
}

\begin{abstract}
Teak plantations in Java show severely declining productivity due to various disturbances. The risk of stand destruction, however, is still ignored in determining annual allowable cuts, partly due to the lack of reliable methods to estimate the rate of stand destruction. This study therefore proposed an alternative method, based on the theory of survival analysis coupled with forest register data, for estimating survival probability and destruction rate of teak plantations. We used the forest register data of teak plantations in Kebonharjo, Central Java, for the period 1977-2007. Survival and destruction of plantations were modeled using probability distribution models. To estimate model parameters, we used the maximum likelihood estimation method designed for left-truncated and right-censored data. Results showed that survival probability and destruction rate varied over stand age and planning period. Rates of stand destruction were relatively low $(<2 \%$ per year) in the period 1977-1987, but increased up to $3 \%$ and $14 \%$ per year in the period 1987-1997 and 1997-2007, respectively. The highest rate of destruction mostly occurred in young stands ( $\leq 30$ years old), indicating an alarming condition for the sustainability of teak plantations. The survival and destruction models are useful for forest managers to quantify the range of historical variability in forest disturbances and to support the development of alternative harvest scheduling methods that incorporate the risk of stand destruction for teak plantations in Java. The proposed method can also be applied to other regions, especially when only forest register data are available.
\end{abstract}

Keywords: teak, destruction rate, survival analysis, Weibull, log logistic

\section{INTRODUCTION}

Teak (Tectona grandis L.f.), the main plantation species in Java, has been managed for over 100 years to produce highquality timber. Javanese teak plantations account for $62.3 \%$ (about 1.1 million ha) of the total area of plantations in Java (Perum Perhutani, 2006) and about 31\% of the total area of teak plantations in the world (PANDEY and BRown, 2000). Such a great resource has obviously provided many benefits not only for generating national income, but also for supporting

Corresponding author: Tatang Tiryana Email: tangtir@ipb.ac.id, tangtir@gmail.com

${ }^{* 1}$ Graduate School of Agricultural and Life Sciences, The University of Tokyo, 1-1-1 Yayoi, Bunkyo-ku, Tokyo 113-8657, Japan

${ }^{* 2}$ Department of Forest Management, Faculty of Forestry, Bogor Agricultural University (IPB), Kampus IPB Darmaga, Bogor 16680, Indonesia the livelihoods of rural communities located in surrounding forests in Java.

Recently, teak plantations in Java, which are managed by Perum Perhutani (PP, a state-owned forestry enterprise), have been facing the serious issue of declining productivity of stands. Between 1994 and 2004, total productive stands decreased from $586,982 \mathrm{ha}$ to $479,106 \mathrm{ha}$, a loss of $18.4 \%$ (ICHWANDI, 2008). This loss was caused by disturbance agents such as illegal logging, forest fire, and grazing (BAILEY and Harjanto, 2005; Ichwandi, 2008; Perum Perhutani, 2006). Forest disturbances, which accelerated during the period of economic crisis (1998-1999), have caused severe destruction that has drastically changed the age structure of teak plantations. Current teak plantations are mostly dominated by young stands ( $\leq 30$ years old), which account for approximately 81\% of the total productive stands (Perum Perhutani, 2006).

Although the effect of forest disturbances on teak plantations is obvious, the potential risk of stand destruction is still ignored in current forest management planning, especially when PP determines annual allowable cuts (AAC) for a certain forest management unit (FMU). SMARTWOOD (2000) argued 
that ignoring the risk of stand destruction in determining AAC using the existing harvest scheduling method, which is a combination of area and volume controls (PERUM PERHUTANI, 1974), may not ensure the sustainability of teak plantations. Currently, PP is seeking an alternative harvest scheduling method that takes the risk of stand destruction into account in order to support sustainable forest management of teak plantations. Thus, estimating survival and destruction of teak plantations is required for supporting the development of alternative harvest scheduling methods. A number of researchers have also noted the importance of estimating survival probability or destruction rates of forest stands for determining harvest levels at risk of destruction. Among others, REED and ERRICO (1986) made several assumptions about fire destruction probabilities in their proposed harvest scheduling model to determine optimal harvest levels. ARMSTRONG (2004) derived fire destruction probability from a lognormal model to evaluate the effect of catastrophic disturbances on optimal timber harvesting. BETTINGER (2010) also emphasized that disturbance rates have commonly been used in forest planning models.

Currently, there are still few methods or models to estimate survival probability and destruction rate of teak plantations. Commonly, PP uses a geometric mean of the proportions of damaged stand areas in each age class as an estimate of 10-year destruction rates (PERum Perhutani, 2007a). Such a simple calculation of destruction rates has limitations in assessing the trend and dynamics of forest disturbances (see WoodAll et al., 2005) that might depend on stand age (see MORITz et al., 2009 for an example of agedependent fire destruction rates). In addition, such approach cannot provide a means to derive destruction rates for any time step (e.g., 1-year or 5-year destruction rates), which are often desirable for evaluating the effect of disturbances on forest resources. For example, ARMSTRONG et al. (2003) used an annual burn rate derived from a lognormal distribution to project the development of forest structures, while ARMSTRONG (2004) used a decadal burn rate derived from such lognormal distribution to evaluate the sustainability of timber harvest at risk of wildfire. Thus, an alternative method that provides parametric models for estimating survival probability and destruction rate is required to support better management of teak plantations.

A promising method to estimate survival probability or destruction rate of teak plantations is survival analysis, a statistical method for analyzing the lifetime of biological organisms or mechanical systems (COLLETT, 2003; KLEIN and MOESCHBERGER, 2003; LAWLESS, 2003). This method has been widely used in medical and biological sciences and other fields, for example, engineering sciences (called reliability or renewal theory) and social sciences (called event history analysis), but relatively few studies have used this method to model the survival or destruction of forest stands. The principle of renewal theory was first adopted by Suzuki in
Japan in 1959 (see RANDALl and GADOw, 1990; SuzUKI, 1984), who developed the theory of gentan (a Japanese word meaning reduction or diminution) probability, which is defined as the probability that forest stands will be harvested within a certain period after planting (SuzUKI, 1984; YosHIMOTO, 2001). Suzuki developed the gentan probability theory in an attempt to revise the concept of normal forest (an ideal forest condition with the same area for each age class) by considering that forest stands may experience clear-cutting at a specific age class. A similar attempt was made by KouBA (1989; 2002), who also proposed a revision of the concept of normal forest by considering the probability of stand destruction due to calamities (e.g., snow, wind, and other natural disturbances). Although KouBA (1989; 2002) used reliability theory for modeling the survival of forest stands, a need remains to improve the estimation method of survival models (GADOw, 2000). Moreover, the estimation of parametric models for deriving gentan probability has been a research issue for several decades in Japan. Among others, BLANDON (1991) introduced censored sample theory, which is widely used in survival analysis, to improve the estimation method of gentan probability. FUJIKAKE (2003) further discussed the applicability of survival analysis for estimating gentan probability by taking into account the issue of censoring and truncation of forest register data.

Few studies have attempted to use the theory of survival analysis for addressing natural resource management problems in tropical countries. VANCE and GEOGHEGAN (2002) used survival analysis linked with satellite imagery and socioeconomic data to investigate deforestation in southern Mexico. Similarly, Greenberg et al. (2005) used survival analysis and satellite imagery to estimate deforestation rates over time in the lowland rain forests of eastern Ecuador. To our knowledge, no studies to date have used survival analysis for modeling the survival or destruction of plantation forests at the FMU level in tropical countries using forest register data obtained from standard forest inventory techniques. We consider that survival analysis as demonstrated by FUJIKAKE (2003) could be extended for modeling survival and destruction of teak plantations.

This study focused on developing survival and destruction models as a first attempt to support the development of alternative harvest scheduling models of teak plantations. Specifically, the objectives of this study were: 1) to demonstrate the applicability of survival analysis coupled with forest register data as an alternative method for estimating the survival and destruction of teak plantations, 2) to develop models for estimating destruction rates of teak plantations in a selected FMU located in Central Java, Indonesia, between 1977 and 2007, and 3) to discuss the applicability of the proposed method for supporting the management of teak plantations. 


\section{MATERIALS AND METHODS}

Study Area

The study was conducted at Kebonharjo FMU, which is one of 57 FMUs managed by PP, located in Central Java, Indonesia $\left(6^{\circ} 37^{\prime} 15^{\prime \prime}-6^{\circ} 58^{\prime} 8^{\prime \prime} \mathrm{S}, 111^{\circ} 26^{\prime} 29^{\prime \prime}-111^{\circ} 43^{\prime} 11^{\prime \prime} \mathrm{E}\right.$; Fig. 1). The total area of Kebonharjo FMU is 17801.3 ha, divided into four forest divisions: Balo (5,544.0ha), Merah (5,610.1ha), Tuder (4,001.9ha), and Gunung Lasem (2,645.3ha). While the first three divisions are managed for teak production, Gunung Lasem is managed for conservation purposes because it is a habitat for various flora and fauna with high conservation value. This FMU has a dry season of 5 months (MaySeptember), with annual rainfall (during the period 2002-2005) of 720-1,155mm (PERUM Perhutani, 2007a).

Teak is the main plantation species in the FMU, accounting for $71.2 \%(12,678.8 \mathrm{ha})$ of the total area, which is managed for producing high-quality timber. The plantations are managed by clear-cutting with an artificial regeneration system. Before 2007, the rotation period was 80 years and regeneration was conducted by involving forest villagers through a tumpangsari program (PERUM PERHUTANI, 2007a). Tumpangsari is a type of agroforestry whereby forest villagers can use forest land for planting agricultural crops (e.g., rice, corn, cassava, soybean, and tobacco) for 2 years, if they also plant and maintain teak trees during this period (PELuso, 1992). This program is widely implemented in Java for establishing plantation forests and can provide mutual benefits for forest villagers and FMUs.

\section{Data Collection and Preparation}

To analyze the survival of teak plantations, using longterm life history data of teak plantations would be more appropriate, but such data were not available. As an alternative, this study used forest register data of Kebonharjo FMU (consisting of Balo, Merah, and Tuder forest divisions) for the period 1977-2007 (PERUM PERHUTANI, 1977; 1987; 1997; 2007b). These data were also used by PP to develop a 10-year management plan for teak plantations for the planning periods 1977-1987, 1987-1997, and 1997-2007.

The forest register data, which came from periodic forest inventories (10-year measurement cycle), contained reliable information about teak stands in each sub-compartment, e.g., the size of stands (in hectares), stand variables (e.g., top height, basal area, and age), and a brief description of stand conditions. PP classified the condition of teak stands in each sub-compartment into productive or unproductive stands based on the basal area density index (GDI), which is defined as the ratio between the current basal area (from forest inventory) and normal basal area (from normal yield tables). The productive stands consist of teak stands with a GDI of at least 0.60 (regardless of stand age), which would survive into the future. The unproductive stands consist of three categories: bare land (stands with GDI $<0.05$ regardless of stand age), undergrowth (stands $\leq 40$ years old and GDI from 0.05 to 0.59 or stand $>40$ years old and GDI from 0.05 to 0.30 ), and understocked (stands $>40$ years old and GDI from 0.31 to

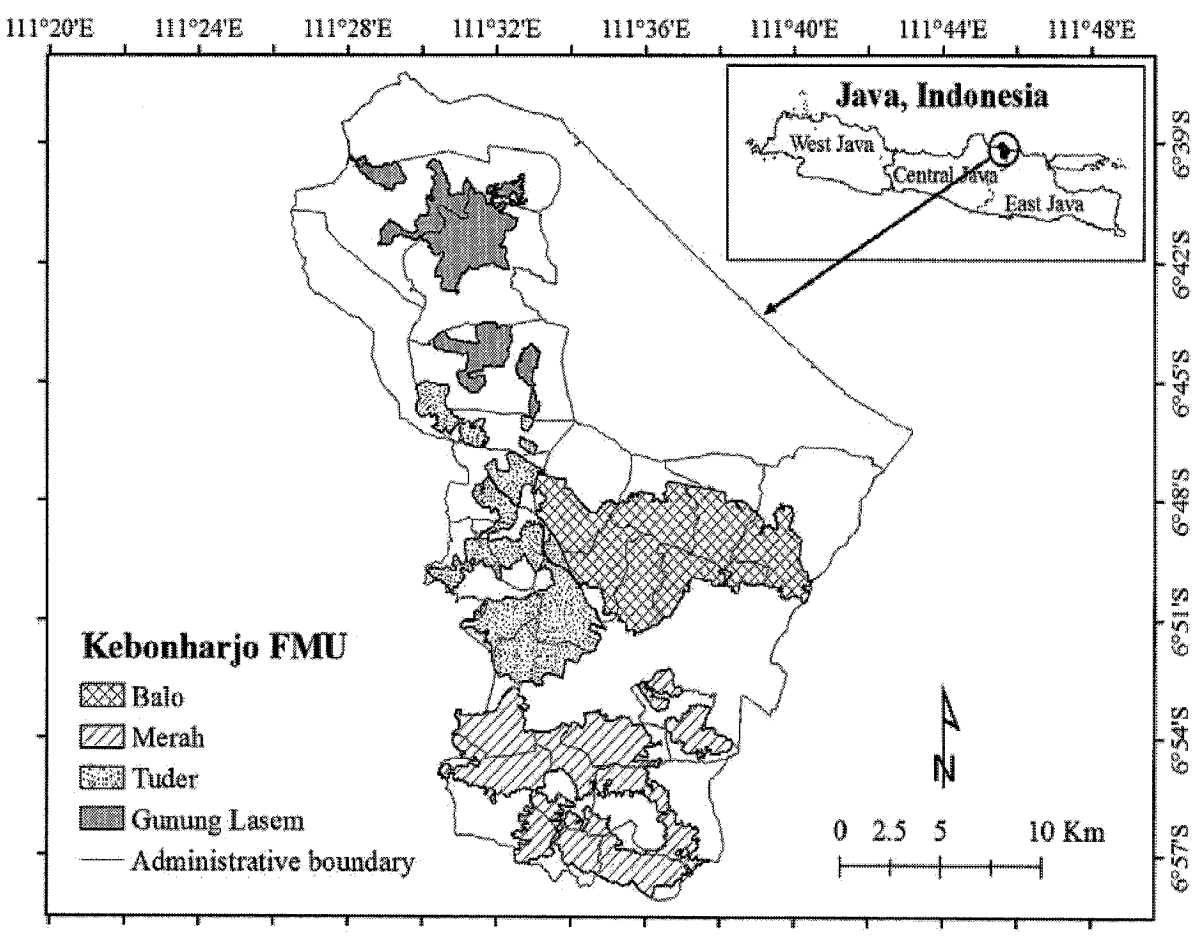

Fig. 1 Kebonharjo FMU, Central Java, Indonesia 
0.59), which resulted from various forest disturbances that occurred during a certain planning period. These unproductive stands would be harvested (called salvage-cutting) and regenerated as soon as possible within a 10-year planning period (Perum Perhutani, 1974). While the productive stands of a specific age class moved to the next age class, the harvested unproductive stands of any age class returned to the first age class in the next planning period.

To perform a survival analysis, it was necessary to define an observation unit. Following some previous studies (e.g., Blandon, 1991; 1993; FujIKAKE, 2003; HoleCY and HANEWINKEL, 2006; RANDALL and GADOW, 1990), this study used stand area (in hectares) as the observation unit by assuming that 1 ha of stand represents one observation unit. The number of subcompartments could not be used as an observation unit, because the boundary and number of sub-compartments after salvage-cutting would change in the following planning period. As a result, the number of sub-compartments varied among planning periods, although the total area of teak plantations remained relatively constant.

To easily calculate the number of damage stands from the forest register data, we summarized the productive stands into seven age classes with 10 -year intervals by considering that the FMU actually harvested some stands at $\geq 71$ years old, which PP calls a minimum cutting age for a rotation of 80 years. Such an age class limitation also aimed to ensure that the loss of productive stands in each age class was merely caused by disturbances that occurred before the final cutting. As a result, we obtained a so-called forest resource table (FUJIKAKE, 2003), which tabulated total standing areas for each age class during the period 1977-2007. By comparing total standing areas at the beginning of one planning period to another (i.e., 1977 and 1987, 1987 and 1997, and 1997 and 2007), the area of damaged stands (i.e., unproductive stands according to PP's classification) between age $t$ and $t+10$ years $(1 \leq t \leq 60), d_{\delta t}$, was calculated as follows (see also FunIKAKE, 2003):

$$
d_{\delta t}=r_{\delta t}-c_{\delta t}
$$

where $r_{\delta t}$ is the standing area (ha) of age $t$ to $t+10$ years at the beginning of the first period (e.g., 1977) and $c_{\delta t}$ represents surviving stand areas (i.e., productive stands according to PP's classification, ha) of age $t$ to $t+10$ years in the first period that move to the next age class in the beginning of the second period (e.g., 1987). These data were then used for survival analysis of teak plantations.

In addition to the forest register data, we also used supporting documents (e.g., management plans and research papers) to explain possible causes of stand destruction that could not be revealed from the forest register data. Field observations and interviews with the FMU staff were also carried out to obtain a better understanding of stand destruction in the study area.
Developing Survival and Destruction Models

We adopted the theory of survival analysis to model the survival and destruction of teak plantations. Comprehensive discussions about this method are available in numerous statistical books, e.g., COLLETT (2003), KLEIN and Moeschberger (2003), LaWless (2003), and NeLson (1982). Here, we only discuss an appropriate method for developing survival and destruction models based on forest register data.

Several methods developed in survival analysis are suitable for specific types of data. FUJIKAKE (2003) pointed out that data summarized into a forest resource table are lefttruncated and right-censored (LTRC). As in our case, the forest resource table did not represent complete information about the lifetime of teak plantations from planting until to the end of their life. The 10-year periodical forest inventory observed the lifetime of existing stands during a 10-year period, so that it only represented a partial snapshot of the lifetime of stands from age $t$ to $t+10$ years (Fig. 2). For a specific age class, no information was available about stands that experienced damage before age $t$ years (e.g., 21 years for age class 3), implying that the lifetime of existing stands was left-truncated at the lower limit of an age class (FujIKAKE, 2003; LAWLESS, 2003). During the 10-year period, some stands in an age class were damaged by various disturbance agents, although we did not know the exact time when destruction occurred between age $t$ and $t+10$ years; however, some other stands would still survive until a specific time in the future. Because the surviving stands were only observed until age $t+$ 10 years for each age class (e.g., 30 years for age class 3 ), the



Fig. 2 Illustration of the construction of the survival function for teak plantations based on left-truncated and rightcensored (LTRC) data (adapted from FuJIKAKE, 2003) The horizontal line with crosses $(-\mathbf{x})$ indicates stands experiencing damage in the interval between age $t$ and $t+10$ years, while the horizontal line with circles $(-\mathbf{o})$ indicates stands that are probably still alive beyond age $t+10$ years. The lifetime of stands is left-truncated at age $t$ years and right-censored at age $t+10$ years. 
lifetime of these stands was right-censored at the upper limit of an age class (Fig. 2). Based on the snapshots of the lifetime of existing stands from age $t$ to $t+10$ years, we reconstructed the survival function of teak plantations that showed a continuous trend in survival from age 1 to 70 years, as we were following the fate of entire teak stands from planting until the end of rotation (see also SKALSKI et al., 2005). Following KoUBA (1989) and HolecY and HANEWINKEL (2006), we modeled the survival and destruction of teak plantations according to stand ages in order to provide survival and destruction models that can be used to derive destruction rates for any time step within a 10year period. Such age-based models could be incorporated into an alternative harvest scheduling model (see e.g., ARMSTRONG, 2004; REED and ERRICO, 1986).

The probability of an individual stand surviving beyond age $t$, implying that stand destruction has not occurred by age $t$, can be expressed by the survival function, $S(t)$, as follows (COLletT, 2003; KLEIN and MOESChBERGER, 2003; LAWLESS, 2003; NELSON, 1982):

$$
S(t)=P(T \geq t)=1-F(t)=\int_{t}^{\infty} f(t) d t
$$

where $T$ is a continuous random variable of the lifetime or age of stands with a certain probability density function $(f(t))$ and cumulative distribution function $(F(t))$. The instantaneous rate of destruction at age $t$, given that the stand survives up to age $t$, is quantified by the following function:

$$
h(t)=\lim _{\Delta t \rightarrow 0} \frac{P(t \leq T<t+\Delta t \mid T \geq t)}{\Delta t}=\frac{f(t)}{S(t)}
$$

This latter function is commonly termed a hazard function in the theory of survival analysis (see e.g. KLEIN and
MoEschberger, 2003), but for the purpose of this study, we termed it a destruction function (see also HOLECY and HANEWINKEL, 2006; KouBA, 1989).

To estimate the survival and destruction functions of teak plantations, we used the maximum likelihood estimation (MLE) method (see e.g., KLEIN and MoEschberger, 2003; LAWLESS, 2003). For LTRC data, the likelihood function consisted of two components: the density function of stand that are damaged at a certain age in the interval $(t, t+10), d_{\delta t}$, conditional on that stands survived to age $t$, and the survival function of stands that survive beyond age $t+10, c_{\delta t}$, conditional on stands having survived to age $t$, which was formulated as follows (FUJIKAKE, 2003; LAWLESS, 2003):

$$
\begin{aligned}
L & =\prod_{0 \leq \leq \leq 60}[P(t \leq T<t+10 \mid T \geq t)]^{d_{t t}}[P(T \geq t+10 \mid T \geq t)]^{c_{t t}} \\
& =\prod_{0 \leq t \leq 60}\left[\frac{S(t)-S(t+10)}{S(t)}\right]^{d_{s t}}\left[\frac{S(t+10)}{S(t)}\right]^{c_{t_{t}}}
\end{aligned}
$$

The number of damaged stands $\left(d_{\delta t}\right)$ and surviving stands $\left(c_{\delta t}\right)$ in this likelihood function was calculated using Eq. (1). We used five probability distribution models: gamma, Weibull, exponential, log logistic, and lognormal (Table 1) in the likelihood function (Eq. (4)), which are commonly used in survival analysis. Appropriate survival models for each planning period were selected based on Akaike's information criterion (AIC; KLEIN and MOESCHBERGER, 2003):

$$
A I C=-2 \log L i k+2 p
$$

where $\log L i k$ is the $\log$-likelihood value of the likelihood function (Eq. (4)) and $p$ is the number of model parameters ( $p$

\begin{tabular}{|c|c|c|c|}
\hline Model & Probability density function $(f(t))$ & Survival function $(S(t))$ & Destruction function $(h(t))$ \\
\hline Gamma & $\frac{1}{\beta^{\alpha} \Gamma(\alpha)} t^{2-1} \exp (-(t / \beta))$ & $1-I(\beta t, \alpha)$ & $\frac{f(t)}{S(t)}$ \\
\hline Weibull & $\frac{\alpha}{\beta^{\alpha}} t^{\alpha-1} \exp \left(-(t / \beta)^{\alpha}\right)$ & $\exp \left(-(t / \beta)^{\alpha}\right)$ & $\frac{\alpha}{\beta^{\alpha}} t^{\alpha-1}$ \\
\hline Exponential & $\lambda \exp (-\lambda t)$ & $\exp (-\lambda t)$ & $\lambda$ \\
\hline Log logistic & $\frac{\alpha t^{\alpha-1} \lambda}{\left(1+\lambda t^{\alpha}\right)^{2}}$ & $\frac{1}{1+\lambda t^{\alpha}}$ & $\frac{\alpha t^{\alpha-1} \lambda}{1+\lambda t^{\alpha}}$ \\
\hline Lognormal & $\frac{\exp \left(-\frac{1}{2}\left(-\frac{\ln t-\mu}{\sigma}\right)^{2}\right)}{\sigma t \sqrt{2 \pi}}$ & $1-\Phi\left(\frac{\ln t-\mu}{\sigma}\right)$ & $\frac{f(t)}{S(t)}$ \\
\hline
\end{tabular}
$=1$ for the exponential model, $p=2$ for the gamma, Weibull, $\log$ logistic, and lognormal models). Models with lower AIC

Table 1 Probability distribution models used in the survival analysis of teak plantations (adapted from KLEIN and MOESCHBERGER, 2003; LAWLESS, 2003; NELSON, 1982)

$\alpha, \beta, \lambda, \mu, \sigma$ are model parameters; $t$ is stand age (years); $I(\beta t, \alpha)=\left(\int_{0}^{t} x^{\alpha-1} \exp (-x) d x\right) / \Gamma(\alpha)$ is a gamma density function; $\Phi(x)=\frac{1}{\sqrt{2 \pi}} \int_{-\infty}^{x} \exp \left(-u^{2} / 2\right) d u$ is the cumulative density function for standard normal distribution. 
values and having simpler forms were considered appropriate for estimating the survival probabilities and destruction rates of teak plantations.

\section{RESULTS}

The age structure of teak plantations during three planning periods (1977-2007; Fig. 3) clearly showed that these plantations never reached normal forest conditions where all age-classes are represented by equal areas. The plantations
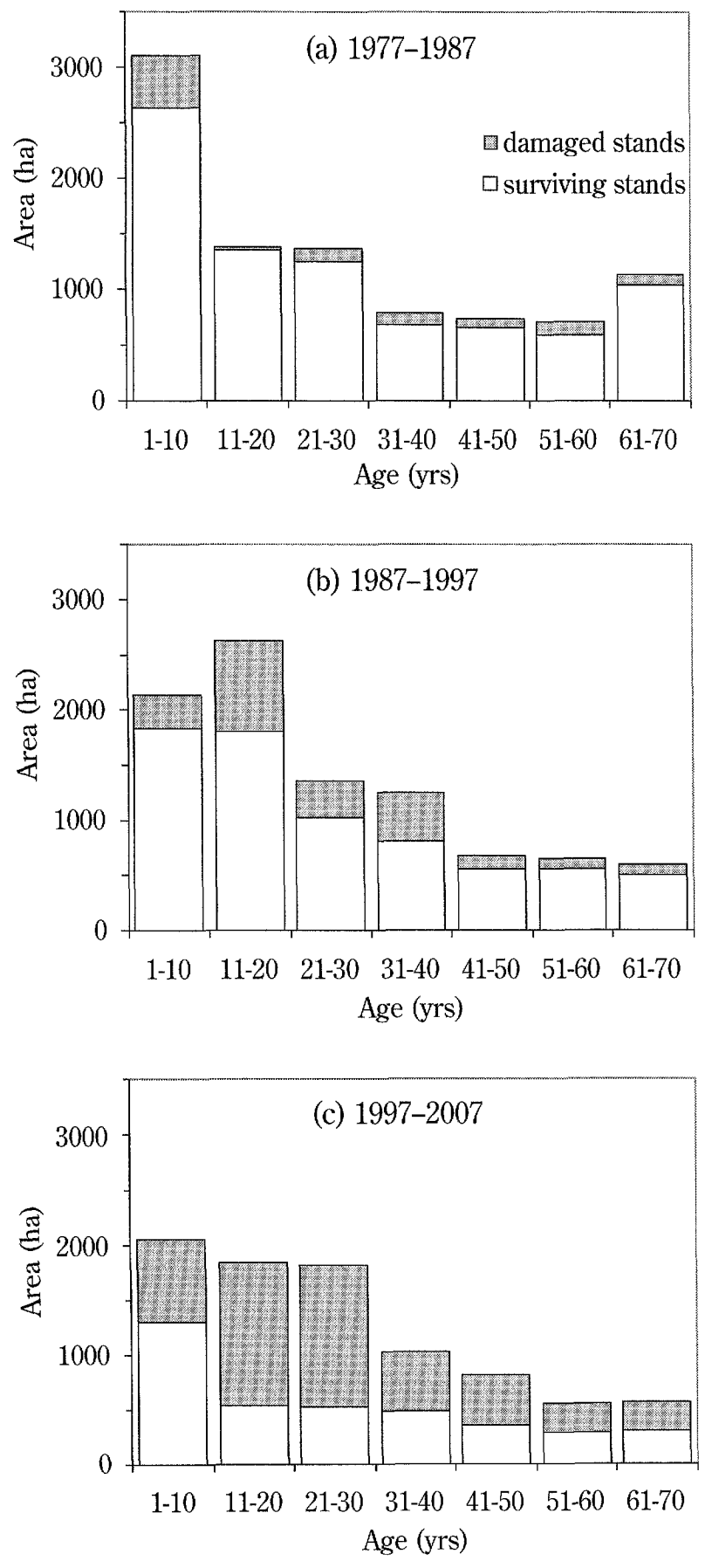

Fig. 3 Age structure of teak plantations in Kebonharjo FMU for the period 1977-2007 were mostly dominated by younger stands, especially those in age classes 1-3. The damaged stands were relatively few (about 11\% of total stand area of age classes 1-7) in the first planning period (1977-1987, Fig. 3a), but then increased (to about $24 \%$ of the total stand area) in the second planning period (1987-1997, Fig. 3b). The most severe damage occurred in the third planning period (1997-2007, Fig. 3c), in which $56 \%$ of the total stand area was damaged by various factors. For each planning period, younger stands $(\leq 30$ years old) tended to experience more severe damage than older stands.

The surviving and damaged stand data (Fig. 3) were modeled using the gamma, Weibull, exponential, log logistic, and lognormal distributions (Table 2). The resulting AIC values indicated that no single model was applicable for all planning periods. For the first planning period, the gamma model was the best-fitting model with the lowest AIC value $(6,405.583)$. However, this model was only slightly better than the Weibull model (AIC $=6,413.091)$ that had simpler functions. Thus, the Weibull model was used to estimate survival probability and destruction rate of the first planning period. For the second and third planning periods, the survival probability and destruction rates were well estimated by the $\log$ logistic model. This model consistently produced the lowest AIC values $(9,973.193$ and $11,220.475)$ compared to the

Table 2 Parameter estimates and AIC values of the gamma, Weibull, exponential, log logistic, and lognormal models used to estimate the survival probability and destruction rate of teak plantations

\begin{tabular}{clrrr}
\hline \multirow{2}{*}{ Model } & \multirow{2}{*}{ Estimates } & \multicolumn{3}{c}{ Period } \\
\cline { 3 - 5 } Gamma & $\alpha$ & $1977-1987$ & $1987-1997$ & $1997-2007$ \\
& $\beta$ & 130.348 & 28.132 & 8.783 \\
& logLik & $-3,200.791$ & $-5,070.961$ & $-5,799.571$ \\
& AIC & $6,405.583$ & $10,145.921$ & $11,603.141$ \\
Weibull & $\alpha$ & 0.847 & 1.113 & 1.165 \\
& $\beta$ & 96.793 & 37.704 & 14.653 \\
& $\log L i k$ & $-3,204.546$ & $-5,084.570$ & $-5,856.759$ \\
& AIC & $6,413.091$ & $10,173.141$ & $11,717.518$ \\
Exponential & $\lambda$ & 0.012 & 0.027 & 0.082 \\
& $\log L i k$ & $-3,219.937$ & $-5,097.833$ & $-5,919.560$ \\
& AIC & $6,441.874$ & $10,197.666$ & $11,841.120$ \\
Log logistic & $\alpha$ & 1.00573 & 1.74212 & 3.18770 \\
& $\lambda$ & 0.01511 & 0.00359 & 0.00034 \\
& $\lambda$ & $-3,226.706$ & $-4,984.596$ & $-5,608.237$ \\
& $\log L i k$ & $6,457.413$ & $9,973.193$ & $11,220.475$ \\
& AIC & 4.164 & 3.248 & 2.483 \\
Lognormal & $\mu$ & 1.695 & 0.957 & 0.630 \\
& $\sigma$ & $-3,242.556$ & $-4,989.233$ & $-5,625.168$ \\
& $\log L i k$ & $6,489.112$ & $9,982.466$ & $11,254.337$ \\
\hline AIC & & &
\end{tabular}

Note: $\log L i k$ is the log-likelihood value (see Eq. (4)). 
other models.

The Weibull and log logistic models resulted in different survival curves (Fig. 4a). The survival probabilities were high in the first planning period, but drastically decreased in the following planning periods. For example, the survival probabilities of teak stands at age 30 years were $0.69,0.43$, and 0.05 , meaning that only about $69 \%, 43 \%$, and $5 \%$ of newly planted teak stands could survive to age 30 years if the damage trends, which were similar to those of the first, second, and third planning periods, respectively, constantly continue into the future. The steepest fall of the survival curve at age $\leq 30$ years in the third planning period indicated that most young stands failed to survive beyond age 30 years.

The risks of stand destruction during the period 19772007 are well illustrated by the destruction rates derived from the Weibull or log logistic models (Fig. 4b). The destruction
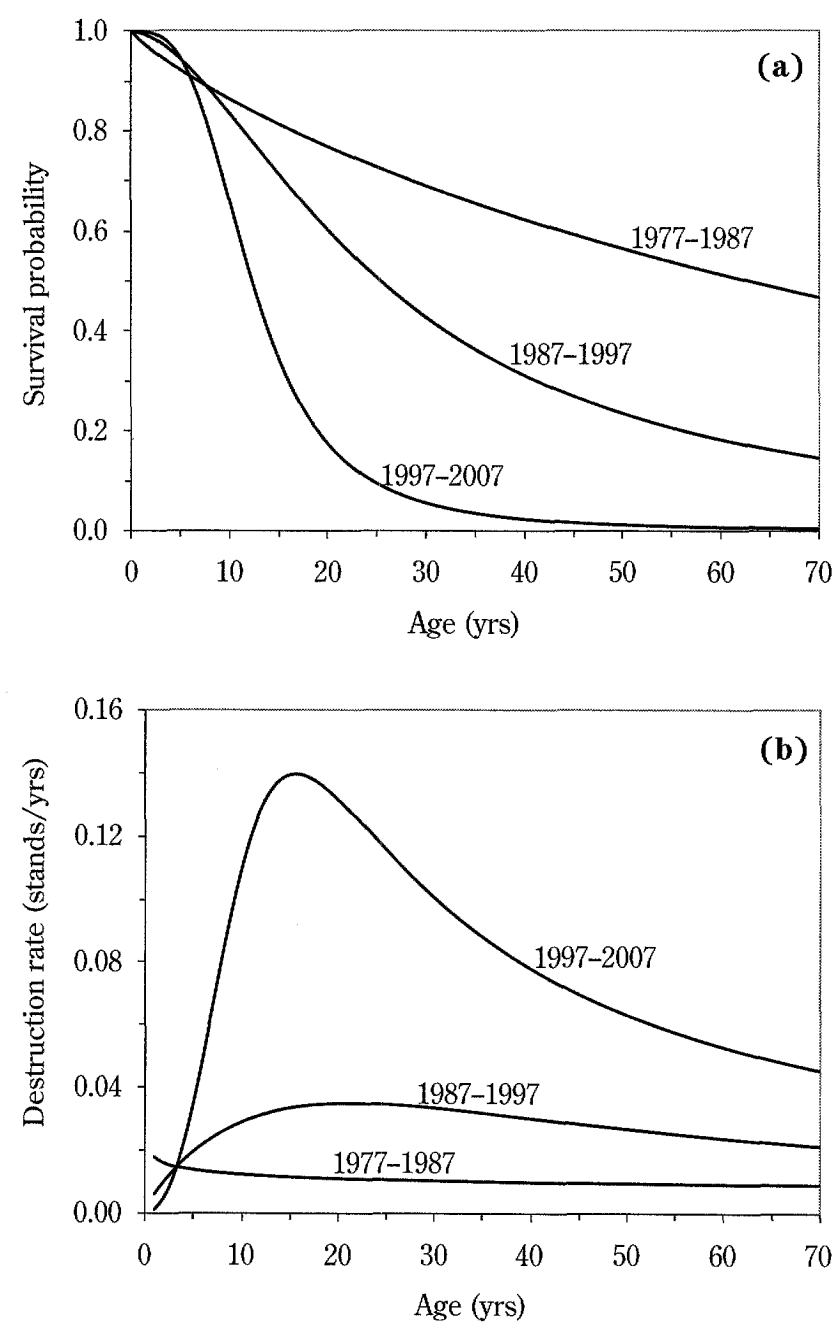

Fig. 4 Survival probability (a) and destruction rate (b) curves for teak plantations in Kebonharjo FMU between 1977 and 2007

The curves of survival probability and destruction rate for the period 1977-1987 were derived from the Weibull model, while those for the periods 1987-1997 and 1997-2007 were derived from log logistic models. rates of teak plantations varied with stand age and seemed to increase from one planning period to another. In the first planning period, destruction rates monotonically decreased with increasing stand age (i.e., from 0.018 to 0.009 per year, or from about $2 \%$ to $1 \%$ per year) when teak stands reached age 1 and 70 years, respectively. In the second and third planning periods, however, the destruction rates formed hump-shaped patterns in which they initially increased until a certain peak and then decreased with increased stand age. The destruction rates reached peaks of $3.5 \%$ per year when stands reached 21 years old at the second planning period, and $14 \%$ per year when stands reached 16 years old at the third planning periods. During the last two planning periods, the destruction rates of young stands ( $\leq 30$ years old) were higher than those of mature stands.

\section{DISCUSSION}

The results showed that the Weibull and log logistics models were appropriate for modeling the survival and destruction of teak plantations. The Weibull model is the most widely used probability distribution model for survival analysis (LAWLESS, 2003). This model offers a flexible shape of probability distribution; it reduces to an exponential model if the shape parameter $\alpha=1$, which is also a unique property of the gamma model (KLEIN and MOESCHBERGER, 2003; LAWLESS, 2003; NELSON, 1982). Compared to the gamma model, which has gained popularity in the study of gentan probability (see e.g. Blandon, 1991; 1993; FujIKAKE, 2003), the Weibull model has more simple probability functions (Table 1) that facilitate easier calculation of the survival probability or destruction rate. Previous studies also showed that the Weibull model was suitable for modeling stand destruction due to calamities (e.g., HolECY and HANEWINKEL, 2006; KouBA, 1989; 2002), and RANDALL and GADOW (1990) suggested it as an alternative model for estimating gentan probability in lieu of the gamma model.

The Weibull and $\log$ logistic models show that the destruction risk of teak plantations is age-dependent, meaning that the rates of stand destruction vary over stand ages. Damage to young teak stands might be caused by forest fire, grazing, and/or fuelwood collection. Forest fire, which occurs every year and is caused by humans and natural factors, has greater potential to damage young stands ( $<5$ years old) than older stands because older stands are more resistant to fire (SYAUFINA et al., 2007). Grazing of villager's livestock (e.g., cows, buffalos, and goats) and fuelwood collection are serious problems for young teak stands. Cattle cause damage by browsing and trampling young trees while they feed (BAILEY and HARJANTO, 2005), resulting in broken stems and soil compaction in young teak stands. Similarly, fuelwood collection conducted by villagers damages young teak stands because villagers tend to slash branches of smaller trees that are easier to handle (BAILEY and HARJANTO, 2005) instead of 
collecting fallen branches of mature trees. Moreover, damage in mature stands is mostly caused by illegal logging or timber theft (Perum Perhutani, 2007a), which has been recognized as the most important factor for stand destruction of teak plantations in Java for hundreds of years (PELuso, 1992).

Unlike some studies on gentan probability that commonly used a gamma model for fitting data of multiple time periods (e.g., Blandon, 1991; 1993; FujIKAKE, 2003), this study suggests that a certain probability distribution model may not applicable for modeling stand destruction of teak plantations at different time periods. The use of different models is reasonable because forest disturbances may change over time. MCCARTHY et al. (2001) argued that different probability distribution models should be considered when modeling fire interval distributions, because the probability of fire can be affected by various biological factors that might change over time. In our case, the Weibull model was only applicable for estimating survival and destruction of teak plantations in the period 1977-1987, while the log logistic models were applicable for the period 1987-1997 and 1997-2007. The forest register data for the period 1977-1987 (Fig. 3a) show that younger stands ( $\leq 10$ years old) experience more damage than older stands. Such a damage trend was well modeled using the Weibull model because this model can represent destruction rates that monotonically decrease as stand age increases (see LAWLESS, 2003). However, the other periods (1987-1997 and 1997-2007; Fig. 3b and 3c) had different damage trends, with damage increasing until a certain peak in younger stands and then decreasing toward older stands. These unimodal damage trends were well represented by the $\log$ logistic models rather than the Weibull model. The differences in intensity of forest disturbances during the three planning periods are a possible reason for the difference in survival and destruction models. PERUM Perhutani (2005) reported that after the economic crisis (1998-1999) the total loss of standing trees due to illegal logging in the study area was about 60 times more than before (1995-1997), resulting in severe damage during the period 1997-2007 compared with the other periods (Fig. 4b). Unfortunately, comprehensive historical data on forest disturbances in the FMU are not available (see also SMARTWOOD, 2000), making it difficult to quantify and compare the amount and intensity of each disturbance agent (i.e., illegal logging, forest fire, grazing, and fuelwood collection) for each period.

The models (Table 2) provide useful tools for forest managers to quantify the range of historical variability (LANDREs et al., 1999) in forest disturbances of teak plantations. Compared to the existing approach used by PP (i.e., using a geometric mean of the proportions of damaged areas), the destruction rate curves (Fig. 4b) offer a better understanding of the variability of destruction rates. Such destruction rate curve may allow a broad comparison of destruction rates (WOODALL et al., 2005) among stand ages and planning periods. The results clearly show that young stands always experience higher destruction than mature stands, suggesting that forest managers should conduct appropriate management activities (e.g., controlling disturbance agents and implementing appropriate silvicultural treatments) for ensuring the sustainability of teak plantations. In addition, the destruction rate curves may also provide better insights into the trend and dynamics of forest disturbance over time. The destruction rates could be considered low ( $<2 \%$ per year), medium (up to $3.5 \%$ per year), and high (up to $14 \%$ per year) for the periods 1977-1987, 1987-1997, and 1997-2007, respectively. Such destruction rate levels may represent the variability of historical disturbances of teak plantations during 30 years, which can be used to develop forest management plans based on natural variability concepts (see LANDRES et al., 1999).

More importantly, as stated in the study objectives, the models can be used to support development of alternative harvest scheduling methods for teak plantations in Java that incorporate the risk of stand destruction. ARMSTRONG (2003) argued that quantifying destruction rates is an important aspect in determining harvest levels that incorporate the rate of forest disturbances. Because the potential risk of forest disturbances cannot be predicted precisely (BETTINGER, 2010; KouBA, 1989), historical destruction rates derived from previous planning periods may provide reasonable measures for assessing the effect of stand destruction on harvest levels. Some previous studies have proposed alternative harvest scheduling methods for integrating the risk of stand destruction into harvest levels. Among others, REED and ERRICO (1986) were one of the researchers who initially developed methods that incorporate stand destruction due to wildfire into a linear programming framework for determining optimal harvest levels. Similarly, KouBA (1989) demonstrated the applicability of survival models coupled with linear and stochastic programming models for determining optimal harvest levels with an attempt to achieve a normal forest condition. Such proposed harvest scheduling models can be further developed for determining optimal harvest levels of teak plantations at risk of destruction. In this case, the survival or destruction models of this study can be integrated in such alternative harvest scheduling models.

This study proposes a promising method based on the theory of survival analysis coupled with forest register data to estimate the survival probability and destruction rate of teak plantations. The use of forest register data to assemble the complete age structure of plantations is an appropriate way to analyze survival or destruction of long-rotation plantations such as teak, because time series data on the fate of plantations from the time of their planting to the end of rotation are very difficult to obtain. Although the forest register data may only represent the age structure of plantations at a specific time, these data are easier to obtain from the existing forest inventory. Such data are also commonly used in fire frequency analysis (MoRITz et al., 2009), survival analysis of wildlife (SKALSKI et al., 2005), and survival 
analysis in large clinical trials (NELSON et al., 2008). More importantly, the estimation of model parameters using the MLE method designed for LTRC data (Eq. (4)) provides an improvement to the estimation method proposed by KouBA (1989; 2002). The proposed method, however, has a limitation because survival probability or destruction rate may not constant over time (SKaISKI et al., 2005). The results also show that stand destruction varied over planning periods (Fig. 4), and thus the population age structure may change over time (SKALSKI et al., 2005). The survival and destruction models developed from this method should be used to evaluate the risk of stand destruction for a particular site and time period. Nevertheless, the models will provide useful tools for improving the existing harvest scheduling method of teak plantations that still ignores the potential risk of stand destruction.

\section{CONCLUSIONS}

This study demonstrated the applicability of survival analysis coupled with forest register data to evaluate the survival and destruction of teak plantations during three planning periods (1977-2007). The Weibull and log logistic models showed that the survival probability and destruction rate of teak plantations were vary over stand age and planning period. The survival models estimated that only about $69 \%$, $43 \%$, and $5 \%$ of newly planted teak stands could survive to age 30 years if the damage trends, which were similar to those of the periods 1977-1987, 1987-1997, and 1997-2007, respectively, constantly continue into the future. In addition, the destruction models indicated that rates of stand destruction were relatively low $(<2 \%$ per year) during the period $1977-$ 1987 , but increased up to $3 \%$ and $14 \%$ per year in the period 1987-1997 and 1997-2007, respectively. The models also showed that the destruction rates of young teak stands were higher than those of older stands. These findings confirmed that teak plantations have always faced a high risk of stand destruction, suggesting that forest managers should conduct appropriate management activities to ensure the sustainability of teak plantations. The survival and destruction models can be used by forest managers to quantify the range of historical variability in forest disturbances, which can be integrated into alternative harvest scheduling methods for teak plantations. While the results of this study might be site-specific, the proposed method is applicable to other regions.

\section{ACKNOWLEDGMENTS}

We thank Perum Perhutani, especially the Division of Forest Planning in Rembang, for permission to use the forest register data, and the staff at Kebonharjo FMU who provided supporting documents. We also thank Dr. Teddy Rusolono of Bogor Agricultural University for valuable discussion about the management of teak plantations in Java. We appreciate the valuable comments and suggestions from anonymous reviewers that greatly improved the content of this manuscript.

\section{LITERATURE CITED}

ARMSTRONG, G., (2004): Sustainability of timber supply considering the risk of wildfire. For. Sci. 50: 626-639

Armstrong, G.W., Adamowicz, W.L., James A., Beck, J., Cumming, S.G. and Schmiegelow, F.K.A., (2003): Coarse filter ecosystem management in a nonequilibrating forest. For. Sci. 29: 209-223

BaileY, J.D. and HaRjanto, N.A., (2005): Teak (Tectona grandis L.) tree growth, stem quality and health in coppiced plantations in Java, Indonesia. New For. 30: 55-65

BetTinger, P., (2010): An overview of methods for incorporating wildfires into forest planning models. Math. Comput, For. Nat. Res. Sci. 2: 43-52

BLANDON, P., (1991): Gentan probability and censored sample theory (I). J. Jpn. For. Soc. 73: 187-196

BLANDON, P., (1993): Unmanaged forests and forecasting using the gentan probability distribution. J. Jpn. For. Soc. 75: 484-492

ColletT, D., (2003): Modelling survival data in medical research. Chapman \& Hall/CRC, New York, 408pp

FUJIKAKE, I., (2003): Estimation of gentan probability based on the forest resource table. Proceedings of the Institute of Statistical Mathematics 51: 95-109 (In Japanese with English summary)

GADow, K.V., (2000): Evaluating risk in forest planning models. Silva Fenn. 34: 181-191

Greenberg, J., Kefauver, S., Stimson, H., Yeaton, C. and Ustin, S., (2005): Survival analysis of a neotropical rainforest using multitemporal satellite imagery. Remote Sens. Environ. 96: 202211

Holecy, J. and Hanewinkel, M., (2006): A forest management risk insurance model and its application to coniferous stands in southwest Germany. For. Policy Econ. 8: 161-174

ICHWANDI, I., (2008): A study on the characteristics of forestry development in Java, Indonesia. $\mathrm{PhD}$ thesis, Kagoshima University

Klein, J. P. and Moeschberger, M. L., (2003): Survival analysis: techniques for censored and truncated data. Springer-Verlag, New York, 536pp

KouBA, V. J., (1989): Control of the conversion process towards the stochastically defined normal forest by the linear and stochastic progamming. Lesnictvi 35: 1025-1040

KoubA, V. J., (2002): Das leben des waldes und seine lebensunsicherheit (Forest life and its temporal uncertainty). Forstwissenschaftliches Centralblatt 121: 211-228

Landres, P.B., Morgan, P. and Swanson, FJ., (1999): Overview of the use of natural variability concepts in managing ecological systems. Ecol. Appl. 9: 1179-1188

LAWLESS, J.F., (2003): Statistical models and methods for lifetime data. John Wiley \& Sons, New York, 664pp

MCCARTHY, M.A., GILl, A.M. and BRADSTOCK, R.A., (2001): Theoretical fire-interval distributions. Int. J. Wildland Fire 10: 7377

Moritz, M., Moody, T., Miles, L., SMith, M. and de Valpine, P., (2009): The fire frequency analysis branch of the pyrostatistics tree: sampling decisions and censoring in fire interval data. Environ. Ecol. Stat. 16: 271-289 
Nelson, C., Sun, J., Tsiatis, A. and Mark, D., (2008): Empirical estimation of life expectancy from large clinical trials: use of lefttruncated, right-censored survival analysis methodology. Stat. Med. 27: 5525-5555

Nelson, W., (1982): Applied life data analysis. John Wiley \& Sons, New York, 634pp

Pandey, D. and Brown, C., (2000): Teak: a global overview. Unasylva 51: $3-13$

Peluso, N. L., (1992): Rich forests, poor people: resource control and resistance in Java. University of California Press, Oxford, 321pp

Perum Perhutani, (1974): Peraturan inventarisasi hutan jati dan peraturan penyusunan rencana pengaturan kelestarian hutan. Perum Perhutani, Jakarta, 68pp (In Indonesian)

Perum Perhutani, (1977): Rencana pengaturan kelestarian hutan kelas perusahaan jati KPH Kebonharjo: Buku A-II, Penyelidikan tentang keadaan hutan untuk jangka perusahaan 1977-1987. Perum Perhutani Unit I Jawa Tengah, Rembang, 782pp (In Indonesian)

Perum Perhutani, (1987): Rencana pengaturan kelestarian hutan kelas perusahaan jati KPH Kebonharjo: Lampiran 1, Register inventarisasi hutan untuk jangka perusahaan 1987-1996. Perum Perhutani Unit I Jawa Tengah, Rembang, 871pp (In Indonesian)

Perum Perhutani, (1997): Rencana pengaturan kelestarian hutan kelas perusahaan jati KPH Kebonharjo: Lampiran tentang pengolahan data elektronik untuk jangka perusahaan 1997-2006. Perum Perhutani Unit I Jawa Tengah, Rembang, 444pp (In Indonesian)

Perum Perhutani, (2005): Hasil kajian terhadap sumberdaya hutan di wilayah KPH Kebonharjo. Perum Perhutani, Tuban, 40pp (In Indonesian)

Perum Perhutani, (2006): Statistik tahun 2001-2005. Perum Perhutani, Jakarta, 230pp (In Indonesian)

Perum Perhutani, (2007a): Rencana pengaturan kelestarian hutan kelas perusahaan jati KPH Kebonharjo jangka perusahaan 1 Januari 2007 sampai 31 Desember 2016. Perum Perhutani Unit I Jawa Tengah, Rembang, 302pp (In Indonesian)

Perum Perhutani, (2007b): Rencana pengaturan kelestarian hutan kelas perusahaan jati KPH Kebonharjo: Lampiran tentang pengolahan data elektronik untuk jangka perusahaan 2007-2016. Perum Perhutani Unit I Jawa Tengah, Rembang, 450pp (In Indonesian)

RANDALL, J. H. and GADOW, K. V., (1990): An evaluation of the use of gentan probabilities in forestry planning. South. Afr. For. J. 154: 27-35

ReED, W. and ERrico, D., (1986): Optimal harvest scheduling at the forest level in the presence of the risk of fire. Can. J. For. Res. 16: 266-278

Skalski, J.R., Ryding, K.E. and Milispaugh, J.J., (2005): Wildlife demography: analysis of sex, age, and count data. Elsevier Academic Press, San Diego, 656pp

SMARTwood, (2000): Smartwood forest management 2000: annual audit report for Perum Perhutani KPH Kebonharjo SW-FM/COC053. Smartwood, New York, 46pp (unpublished report)

Suzuki, T., (1984): The gentan probability, a model for the improvement of the normal forest concept and forest planning. In: Nagumo, H., Konohira, Y., Kobayashi, S., Minowa, M., Nishikawa, K., Narto, K., Sweda, T., Amano, M. and Tanaka, K. (eds) Proceedings IUFRO symposium on forest management planning and managerial economics. University of Tokyo, Tokyo: 12-24

Syaufina, L., Nuruddin, A.A., Rachmatsyah, O. and Husaeni, E.A., (2007): Fire season and class in teak plantations of Central Java, Indonesia. Malay. For. 70: 31-40

VANCE, C. and GEOGHEGAN, J., (2002): Temporal and spatial modelling of tropical deforestation: a survival analysis linking satellite and household survey data. Agric. Econ. 27: 317-332

Woodall, C., Grambsch, P. and Thomas, W., (2005): Applying survival analysis to a large-scale forest inventory for assessment of tree mortality in Minnesota. Ecol. Model. 189: 199-208

Yosнimoto, A., (2001): Application of the logistic, Gompertz, and Richards growth functions to gentan probability analysis. J. For. Res. 6: $265-272$

(Received 5 May 2010)

(Accepted 30 November 2010) 